\title{
Workplace Violence and Perspectives of Healthcare Professionals on Electronic White Code System
}

\author{
İşyerinde Şiddet ve Sağlık Çalışanlarının Elektronik \\ Beyaz Kod Sistemine Bakış Açısı
}

Gülcan AYDIN (iD), Yusuf Yalçın ILERi

\begin{abstract}
The aim of the study was to investigate the white code implementation in a public hospital which intends to provide security for healthcare professionals to reduce the risks of being exposed to workplace violence (WPV) by patients and patient relatives. In this study, 109 WPV cases in Afyonkarahisar Public Hospital were examined. According to study results; mostly female healthcare professionals $(63,3 \%)$ were exposed WPV while the aggressors were male $(72,4 \%)$ in most cases. Most of the WPV incidents happened in the Emergency Department $(35,7 \%)$ and hallways $(26,6 \%)$. Frequent violence type was verbal violence $(50,4 \%)$ and physical violence $(21,1 \%)$ followed it. Participants believed that white code system had a positive effect on preventing WPV incidents, still the violence was inevitable. The main reason underlying WPV incidents was determined due to long waiting times for treatment and low communication capabilities. Study results suggest to decrease the number of WPV incidents; white code applications should be implemented in healthcare institutions, healthcare professional should be trained about WPV, how to keep from violence incidents and what to do in case of WPV, make them feel that the managers and the institution are behind them.

Keywords: Workplace violence, Healthcare, White Code.
\end{abstract}

\section{ÖZET}

Çalışmanın amacı, sağlık çalışanlarının, hastalar ve hasta yakınları tarafından işyeri şiddetine maruz kalma risklerini azaltmayı amaçlayan ve beyaz kod uygulamasını hayata geçiren bir devlet hastanesinde, şiddet olaylarını beyaz kod uygulaması üzerinden incelemektir. Bu çalışmada Afyonkarahisar Devlet Hastanesi'nde yaşanan 109 çalışana şiddet vakası incelenmiştir. Çalışma sonuçlarına göre; çoğunlukla kadın sağlı çalışanları $(\% 63,3)$ işyeri şiddetine maruz kalırken, çoğu vakada saldırganlar erkektir (\% 72,4). Şiddet olaylarının çoğu Acil Servis $(\% 35,7)$ ve koridorlarda $(\% 26,6)$ meydana gelmiştir. Sıklıkla görülen şiddet türleri sözlü şiddet (\% 50,4) ve fiziksel şiddettir (\% 21,1). Katılımcılar, beyaz kod sisteminin işyeri şiddeti olaylarının önlenmesinde olumlu bir etkisi olduğuna inanmakla birlikte yaşadıkları şiddetin kaçınılmaz olduğunu vurgulamışlardır. Sağlıkta şiddet olaylarının altında yatan ana nedenlerin tedavi için uzun bekleme süreleri ve iletişim eksikliği olduğu belirlenmiştir. Çalışma sonuçları, sağlık kurumlarında işyeri şiddeti olaylarının sayısının beyaz kod uygulamaları ile azaltılabileceğini göstermektedir. Sağlık çalışanları şiddet olaylarından nasıl korunabilecekleri ve işyerinde şiddet olayı esnasında neler yapılacağı konusunda eğitilmeli, yöneticilerin ve kurumun çalışanların arkasında olduğu hissettirilmelidir. Anahtar Kelimeler: İșyerinde șiddet, Sağlık Hizmetleri, Beyaz Kod.

Gülcan AYDIN | gulcan.aydin2@saglik.gov.tr

Afyonkarahisar State Hospital, Emergency Service, Afyonkarahisar, Turkey

Yusuf Yalçın íteRi | yusuf.ileri@gmail.com | Corresponding Author Necmettin Erbakan University, Faculty of Health Sciences, Konya, Turkey 


\section{INTRODUCTION}

In many countries, since 1920 's to today, the health policies and had undergone important changes. The healthcare institutions and any services provided by them had met with a modern and organized structure with the healthcare applications which were developed within the framework of adaptation period to new regulations in order to meet new needs and expectations [1]. No matter how well established the healthcare systems are, healthcare professionals have a great influence on the system to function as planned and desired. At this point, the importance of the moral, motivation and working with feeling safe of healthcare workers is clearly understood highly motivated healthcare workers would be more productive, work with less mistake and increase the quality of service [2]. Relatively it will positively affect patients receiving the expected healthcare services and satisfied with the institution [3]. Providing the service under decent conditions, paying the proper amount of salary, the right type of management system and the positive communication between the patient and the healthcare professionals are considered as factors that increase the motivation. However, such situations as the occupational risks, falling behind of the demand to healthcare due to increase in the population, bring the inconveniences in regards of both for healthcare personnel and patients [4-5].

Plenty of factors are shown that affect the motivation of healthcare professionals in the literature but one of the most important factor is feeling safe. Recently, workplace violence (WPV) against healthcare professionals is increasing especially in developing countries [6]. Although there are many reasons, the difficulty in meeting the demand for healthcare services and injustice in accessing services stands out the most important reasons for the rapid increase [1].
Studies have showed that health care workers are the professionals most vulnerable to WPV [7]. WPV can affect the physical and mental health of victims, violence against healthcare workers is a major problem affecting productivity, directly cause absenteeism and degrade the work climate and morale of healthcare workers [8-9].

Thus, the occupational safety comes into prominence. It is essential to possess the ability to organize at a fast pace in case of situations that need immediate solutions. In terms of qualified and quality healthcare service, the security of patients and the healthcare professionals must be prioritized [10]). The security services in the hospitals aim to prevent the healthcare professionals from the negative effects of WPV in physical or psychological terms [5-8]. Within this framework, the risk management must be executed in proper manner. In order to increase the efficiency of the risk management and to have the ability of controlling emergency situations, "white code emergency systems" are developed [11].

There are studies in the literature that examine the violence against healthcare professionals. Annagür [12] claims that the ratio of facing to WPV in the emergency rooms in Canada is quite high and the frequency of WPV is $60 \%$ and the majority of victims are women. Turkan stated that in certain European countries (Belgium, Germany, Finland, France, Italy, Poland, Slovakia and the Netherlands) $22.7 \%$ of the healthcare professionals faced violent attacks by patients and patient relatives. While in Turkey the violence against healthcare professionals aggravate as gradually increasing. The percentage of healthcare workers who officially filled complaints due to WPV and abuse shown as $58 \%$, along with this fact, this rate manifests itself in a higher number in public hospitals in comparison to private hospitals [13]. According to Akça’s et al [14] research in a private medical center located in Ankara province, it was 
determined that $24.2 \%$ of the healthcare workers was exposed WPV. In addition, according to study results, WPV emerges due to variety of causes such as; long waiting hours, overcrowded areas, the inconveniences during communication, social and cultural behaviors. However, the research conducted by Bıçkıcı in a public hospital, showed that the frequency of physical violence was $7.7 \%$ and exposure to both verbal and physical violence was 55.8\% [15] .

Finally, various measures and precautions have been taken in order to control or eliminate any emergency that may occur in healthcare institutions. The Color Codes are considered as the most common emergency management tools in the world. Color codes and their applications vary depending on the nature of the emergency situation. The very first examples emerged in the United States and white code system is the most effective instrument to control WPV incidents [3-16].

Almost all studies concerning violence in health were conducted in healthcare institutions that did not have a white code system which objectively records and presents the details of the violence incident. However, the white code system is the best and precise way to present the number and details of violence events and the victims of these events in healthcare institutions. For this reason, we beleive that, it is important to study workplace violence in an healthcare institution which has a white code system and actively uses it.

In this research, we aimed to investigate to the "White Code" implementation in a public hospital which intends to provide security for healthcare professionals to reduce the risks of being exposed to verbal, physical, psychological and sexual abuse posed by patients and patient relatives. Moreover, we aimed to clarify the opinions of healthcare professionals who experienced workplace violence and trig- gered white code sequence. In this context, the study results may contribute the literature to comprehend the characteristics of workplace violence in healthcare institutions and give hints to healthcare managers to reveal possible solutions against WPV which is a growing and displeasing problem.

\section{METHODOLOGY}

This study was carried out in the screening model. Screening models aim to describe a situation that is in the past or that already exists at present. Screening models do not try to change or influence the individual or the object that is subject to the research and it is essential to conduct observation appropriately and define the matter. In this study, the "general screening" model of the screening model was used. General screening models are used with the purpose of making a general judgment about the universe which consists a large number of elements and screening arrangements made on a group or sample taken from the universe [17].

The questionnaire in the study was prepared by the researchers and it was arranged and implemented in line with expert opinions including two healthcare managers, a social worker and a quality manager. The questionnaire was implemented on a voluntary basis to healthcare workers in Afyonkarahisar Public Hospital who were exposed workplace violence and reported "White Code Study Form". The questionnaires were implemented using face to face interview method with the volunteers.

\section{A. How The White Code System Works}

In different hospitals healthcare professionals can trigger a white code sequence in case of WPV in different ways. In the redacted hospital, healthcare professionals trigger a white code sequence calling " 1111 ” using any 
phone in the hospital. After the call, white code team immediately arrives at incident area as quick as possible. The team consists of security guards and if there is a need a social worker may assist them. Details about the incidents are gathered using "White Code Study Form" and stored in a database.

\section{B. Study Location And Sampling}

The study consists of 109 healthcare professionals (69 female and 40 male) working in Afyonkarahisar Public Hospital. The participants consist of doctors, nurses, medical officers, medical secretaries, and other healthcare workers who had worked in Afyonkarahisar Public Hospital which have 800 patient beds. Participants were exposed workplace violence, triggered white code sequence and reported statement of "White Code Study Form" in the last one year. The study analysis was concluded in 2019.

\section{Data Collection Process}

In the study, a questionnaire form developed by the researchers was used as the data collection tool. The questionnaire consists of questions to determine sociodemographic characteristics and questions to specify the details of white code incidents. The first part of the questionnaire contains 8 socio-demographic questions such as; age, sex, marital status, level of education, institution, occupation, department and professional experience of the healthcare workers. The second part of the questionnaire consists of 24 questions having propositions in 5 Likert scale which was designed to measure the attitudes of employees towards the white code system.

\section{Data Analysis}

The data was analyzed using frequency (n), percentage (\%), mean, standard deviation, minimum and maximum values. Chi-Square test was used to compare two categori- cal independent variables and to determine the level of relationship, Phi and Cramer's V coefficient used as a base and statistical significance was estimated at $\mathrm{p}<0,05$ level. SPSS 24.0 was used for the statistical analysis.

\section{E. Ethics}

In order to conduct the research, necessary permissions were obtained from Afyonkarahisar Public Hospital and Afyonkarahisar Provincial Health Directorate and ethics permission was obtained from Afyonkarahisar Health Sciences University Clinical Research Ethics Committee (No: 44946004-602.01.01/2018). Researchers declare that the article follows research and publication ethics.

\section{RESULTS}

In the study, out of 109 participants, 69 (63.3\%) of them were female and $40(36.7 \%)$ of them were male and $61.5 \%$ of them were married while $38.5 \%$ were single as shown in Table 1. The average age of the participants was $35.66 \pm 8.11$ years, the youngest participant was 21 years old, and the oldest participant was 63 years old. The education status of the participants were as follows; $8.3 \%$ of them graduated from high school, $22 \%$ of them had associate degree, $26.6 \%$ had undergraduate degree, $44.1 \%$ had graduate degree. In the study, the average duration of experience of participants was $12.69 \pm 8.17$ years, the minimum period of experience was 2 years and the maximum period of experience was 38 years. Considering the distri-

Table 1. Gender frequency distribution of the participants

\begin{tabular}{|c|c|c|c|c|c|}
\hline \multicolumn{6}{|c|}{ Marital Status } \\
\hline & Type of & ence & Married & Single & Total \\
\hline \multirow{4}{*}{$\begin{array}{c}\text { Gender of } \\
\text { the } \\
\text { Participants }\end{array}$} & \multirow{2}{*}{ Female } & $\mathrm{N}$ & 41 & 28 & 69 \\
\hline & & $\%$ & 59,4 & 40,6 & 63,3 \\
\hline & \multirow{2}{*}{ Male } & $\mathrm{N}$ & 26 & 14 & 40 \\
\hline & & $\%$ & 65 & 35 & 36,7 \\
\hline & \multirow{2}{*}{ Total } & $\mathrm{N}$ & 67 & 42 & 109 \\
\hline & & $\%$ & 61,4 & 38,6 & 100,0 \\
\hline
\end{tabular}


Table 2. Frequency distribution of the type of violence encountered

\begin{tabular}{|c|c|c|c|c|c|c|c|}
\hline & Type of $\mathrm{V}$ & & Verbal & Physical & Psychological & Emotional & Total \\
\hline \multirow{8}{*}{$\begin{array}{l}\text { The Genders of the Parti- } \\
\text { cipants }\end{array}$} & \multirow{2}{*}{ Female } & $\mathrm{N}$ & 40 & 9 & 13 & 7 & 69 \\
\hline & & $\%$ & 57,9 & 13,1 & 18,8 & 10,2 & 63,3 \\
\hline & \multirow{3}{*}{ Male } & $\mathrm{N}$ & 15 & 14 & 5 & 6 & 40 \\
\hline & & & & & & & \\
\hline & & $\%$ & 37,5 & 35 & 12,5 & 15 & 36,7 \\
\hline & \multirow{3}{*}{ Total } & $\mathrm{N}$ & 55 & 23 & 18 & 13 & 109 \\
\hline & & & & & & & \\
\hline & & $\%$ & 50,5 & 21,1 & 16,5 & 11,9 & 100,0 \\
\hline
\end{tabular}

bution of the weekly working hours of the participants, it was seen that $66.1 \%$ work $40-50$ hours, $33 \%$ work $50-70$ hours, and $0.9 \%$ work less than 40 hours a week. The working forms of the participants were as follows; $79.8 \%$ of them work as daytime shifts and shifts, $10.1 \%$ work as variable shifts, $9.2 \%$ work as $08-17$ weekdays, and $0.9 \%$ work as daytime shifts. Considering the distribution of the type of violence faced by healthcare professionals, results show that $50,5 \%$ of them faced verbal abuse, $21,1 \%$ faced physical violence, $16,5 \%$ faced psychological violence and $11,9 \%$ faced emotional violence as given in Table 2 .

It was determined that $53.2 \%$ of the participants initiated the white code themselves during or just after the violence incident, while $46.8 \%$ could not initiate the white code themselves, instead a colleague initiated the system.

The duration of time for white code team to intervene the violence incident is critically important. We also exam- ined how long it takes for white code team to arrive at incident point. Results show that; the white code team arrived within first 1-5 minutes after white code initiation in the $76,1 \%$ of the incidents, first 5-10 minutes in $13,8 \%$ of incidents, first $10-15$ minutes in 5,5\% of incidents, first 15-20 minutes in 2,8\% of incidents, first 25-30 minutes in $9 \%$ of incidents and in one incident $(0,9 \%)$ the team did not arrive at violence incident point. The reasons behind their late arrivals to the situations were asked to the team which had taken longer than 5 minutes, the received answers can be gathered in two groups: many tasks given at the same time and disruptions in the call system (late receiving or not receiving of the white code initiation). As given in Table 3, 69,7\% of the participants were exposed to WPV from patient relatives, $12,8 \%$ of the participants were exposed to WPV directly from the patient, 9,2\% of them were exposed to WPV from both patient and patient

Table 3. Frequency distribution of the gender of the participants and the identity of the aggressors.

\begin{tabular}{|c|c|c|c|c|c|c|c|}
\hline & Aggre & & Patient & $\begin{array}{l}\text { Patient } \\
\text { Relative }\end{array}$ & $\begin{array}{c}\text { Patient and Patient } \\
\text { Relative }\end{array}$ & Other & Total \\
\hline \multirow{4}{*}{$\begin{array}{l}\text { The Genders of the } \\
\text { Participants }\end{array}$} & \multirow{2}{*}{ Female } & $N$ & 11 & 51 & 3 & 4 & 69 \\
\hline & & $\%$ & 15,9 & 73,9 & 4,3 & 5,9 & 63,3 \\
\hline & \multirow{2}{*}{ Male } & $\mathrm{N}$ & 3 & 25 & 7 & 5 & 40 \\
\hline & & $\%$ & 7,5 & 62,5 & 17,5 & 12,5 & 36,7 \\
\hline & \multirow{2}{*}{ Total } & $\mathrm{N}$ & 14 & 76 & 10 & 9 & 109 \\
\hline & & $\%$ & 12,8 & 69,7 & 9,2 & 8,3 & 100,0 \\
\hline
\end{tabular}


relatives, lastly $8,3 \%$ of them were exposed WPV from other people they did not know. Most of the aggressors were male $(72,4 \%)$ while $27,6 \%$ of the aggressors were female.

Study results also reveal that; $60,6 \%$ of the participants were exposed to WPV at least 5 times or more, while $12,8 \%$ of them only once, $11,9 \%$ of them twice, $11,9 \%$ of them 3 times and lastly $2,8 \%$ of them were exposed to WPV 4 times .

As mentioned in the introduction of the study, facing workplace violence may affect healthcare professionals deeply. According to the study results; $60,6 \%$ of the participants were able to return to work within 1-5 minutes right after the violence incident, $4,6 \%$ of them within 5-15 minutes, $15,6 \%$ of them within $15-30$ minutes, $6,4 \%$ of them within $30-60$ minutes, $8,3 \%$ of them within $60-120$ minutes and $1,8 \%$ of them were able to return to work within 120-180 minutes. Whereas, $1,8 \%$ of them were able to return to work within 1 day or longer timespan after the violence incident happened and $0,9 \%$ of them resigned after the violence incident.

Study results show that; $90,8 \%$ of the participants did not receive psychological counseling service. However, $4,6 \%$ of them received psychological counseling service irregularly and $4,6 \%$ of them received regular psychologi- cal counseling service. When the drug usage situation is examined among the workers who received psychological counseling service, it was determined that, $16,7 \%$ of them have used drugs for a while after the workplace violence incident. In order to understand the effects of WPV over healthcare professionals, we asked them to clarify how they felt after the incidents. Results show that; $71,6 \%$ of them felt anger, 67\% of them experienced anxiety, 54,1\% of them felt inquietude, $46,8 \%$ of them felt disappointed, $39,4 \%$ of them were in perplexity, $23,9 \%$ of them felt distrust to the institution they work because it did not take necessary actions to secure them, $18,3 \%$ of them experienced post-traumatic stress disorder, $16,5 \%$ of them experienced extreme fatigue and loss of confidence, $11,9 \%$ of them felt despair and fear, $9,2 \%$ of them were in avoidance or in extreme precautionary behaviors, $7,3 \%$ of them experienced depressive adjustment disorder, 4,6\% of them showed signs of fear from their patients and felt the feeling of being left alone and helpless and 3,7\% of them them them experienced social disorders along with facing the physical effects of mental distress.

Study results about the root cause(s) of the violence incidents were as follows; $81,7 \%$ of the participants stated that the root cause of the incident derived from the neglect of patient relatives in terms of awareness, $42,2 \%$ of the

Table 4. Frequency distribution of the genders of the participants and the location of the violence incident

\begin{tabular}{|c|c|c|c|c|c|c|c|c|}
\hline & Location & & $\begin{array}{l}\text { Waiting } \\
\text { Room }\end{array}$ & $\begin{array}{l}\text { Emergeny } \\
\text { Room }\end{array}$ & Examination Room & Hallway & Other & Total \\
\hline \multirow{8}{*}{$\begin{array}{l}\text { Genders of } \\
\text { the Participants }\end{array}$} & \multirow[b]{2}{*}{ Female } & $\mathrm{N}$ & 1 & 19 & 17 & 24 & 8 & 69 \\
\hline & & $\%$ & 100, & 48,7 & 70,8 & 82,8 & 50,0 & 63,3 \\
\hline & \multirow{3}{*}{ Male } & $\mathrm{N}$ & 0 & 20 & 7 & 5 & 8 & 40 \\
\hline & & & & & & & & \\
\hline & & $\%$ & 0,0 & 51,3 & 29,2 & 17,2 & 50,0 & 36,7 \\
\hline & \multirow{3}{*}{ Total } & $\mathrm{N}$ & 1 & 39 & 24 & 29 & 16 & 109 \\
\hline & & & & & & & & \\
\hline & & $\%$ & 100,0 & 100,0 & 100,0 & 100,0 & 100,0 & 100,0 \\
\hline
\end{tabular}


participants stated that the root cause was the followed healthcare policies, $41,3 \%$ of the participants stated that the root cause was the idea that the person who is engaged with the violence firmly believes that he/she is entitled to do so, $36,7 \%$ of the participants believed that the root cause was the highness in the number of patients, $21,1 \%$ of the them stated that the root cause of the incident derived from the miscommunication and misunderstanding, $16,5 \%$ believed it was the idea that the person who is engaged with violence believes that he/she is neglected in terms of receiving healthcare, $15,6 \%$ believed it was the fact that the person who is engaged with violence was under influence of certain substances such as alcohol or medication, $11,9 \%$ believed it was dissatisfaction of the treatment implemented to patient, 9,2\% believed it was the excessive workload in hospitals, $6,4 \%$ believed it was long waiting hours.

Other important details of WPV are whether the incident happened when healthcare professionals were alone and the location of the incident. According to study results; $86,2 \%$ of the participants were not working alone at the time of violence incident and $13,8 \%$ of the participants were working alone at the time of violence incident. In Table 4 the distribution of locations where violence took place was given. $35,8 \%$ of the incidents happened in the emergency room, $26,6 \%$ of them happened in the hallways, $22 \%$ of them happened in examination rooms/ polyclinics, $15,6 \%$ of them happened in other places in the hospital like waiting rooms, hospital garden, hospital entrances, car park etc.

Study results show that; $75,2 \%$ of the healthcare professionals asked for help as reaction to the violence incident, $71,6 \%$ of them responded with self-defense and $4,6 \%$ of them could not take any reaction. In $32,1 \%$ of the incidents other people showed up to help healthcare professionals.

In our study, $82,6 \%$ of the participants stated that judicial proceedings took place after the WPV incident happened, $56 \%$ of the participants filed complaints and pressed charges and only $3,7 \%$ of them took no action against attackers. As seen in Table 5, 63,3\% of the participants still feel highly concerned about facing violence again while performing their duty, $25,6 \%$ of the participants sometimes feel concerned and $11,1 \%$ of the participants do not feel concerned about facing violence again while performing their duty. Study results indicate that; $86,2 \%$ of the participants did not receive any training about the white code application implemented in the hospital. Still, they were familiar with the system and knew how to use it.

Table 5. Frequency distribution of the participants whether they still feel concerned about facing violence again while performing their duty

\begin{tabular}{|c|c|c|c|c|c|c|}
\hline & & & Yes & Sometimes & No & Total \\
\hline \multirow{6}{*}{ The Genders of the Participants } & Female & $\mathrm{N}$ & 48 & 12 & 9 & 69 \\
\hline & & $\%$ & 69,5 & 17,3 & 13,2 & 63,3 \\
\hline & \multirow[b]{2}{*}{ Male } & $\mathrm{N}$ & 21 & 16 & 3 & 40 \\
\hline & & $\%$ & 52,5 & 40 & $7,5 \%$ & 36,7 \\
\hline & \multirow[b]{2}{*}{ Total } & $\mathrm{N}$ & 69 & 28 & 12 & 109 \\
\hline & & $\%$ & 63,3 & 25,6 & 11,1 & 100,0 \\
\hline
\end{tabular}


Participants have mostly appreciated the implementation of the white code system as $69,7 \%$ of the participants stated that the system had a positive effect on their motivation while performing their duties.

One of the most important results of the study was about the efficiency of the system. $67,9 \%$ of the participants believed that the implementation of the white code system was effective in terms of preventing workplace violence and directly had impact on decreasing the number of workplace violence incidents as a deterrent. Moreover, $69,7 \%$ of the participants stated that the WPV incident they had faced could not be prevented in any way because the patient/patient relative was determined to do so.

In the study, the relationship between the gender of the participants and the type of violence they encountered with was statistically significant $(\mathrm{p}<0,05)$. It was observed that there was a significant, positive and low-level relationship ( $\mathrm{p}=0.029)$ between the genders of the healthcare workers and the type of violence faced, and the rate of male participants who experienced physical violence (60.9\%) was higher than other violence types (for example, males exposed rate to verbal violence was $27.3 \%)$. No significant relationship was found between the gender of the participants and the effect of white code on job motivations $(\mathrm{p}=0.361)$.

Statistically significant relationship was found between the genders of the participants and triggering the white code sequence on own $(\mathrm{p}=0.494)$, there was a statistically significant, positive and low-level relationship $(\mathrm{p}=0.045)$ between the genders of the healthcare workers and the identity (patient or patient relative) of the aggressor, similarly there was a statistically significant, positive and midlevel relationship $(\mathrm{p}=0.002)$ between the genders of the participations and the genders of the aggressors. Study results showed that; the rate of female patient/patient relatives $(\% 86,7)$ engaged in aggression towards female healthcare workers was higher compared with the rate of male patient/patient relatives $(\% 54,4)$ who engaged in aggression towards female healthcare workers.

It was observed that there was a statistically significant, positive and low-level relationship $(\mathrm{p}=0.032)$ between the gender of healthcare professionals and their anxiety about facing violence again while performing their duties and there was a statistically significant, positive and mid-level relationship $(\mathrm{p}=0.030)$ between the genders of the healthcare workers and the place they were attacked. According to the results $82.8 \%$ of WPV incidents in hallways were towards female healthcare workers.

\section{DISCUSSION AND CONCLUSION}

Violence in the workplace is an important problem for every professional service sector. However, within the healthcare sector, despite increasing and enacted laws, it has become an unavoidable problem. This is actually a long standing problem in healthcare sector. In 1997, Elliot stated that people working in healthcare institutions carry 16 times more risks in terms of being exposed to violence than those working in other sectors. Although there are studies investigating the violence in healthcare in the literature, there are very few studies examining workplace violence incidents in healthcare including the White Code System.

In the vast majority of the studies similar with our study results, it was determined that the most exposed group to WPV was female healthcare professionals, and the most common aggressor part was male patients and their relatives [19-20].

In a study conducted by Kaya [21], 107 white code cases were examined and it was determined that $46.7 \%$ of 
violence cases were directed towards women and 53.3\% were directed at men. In our research, unlike the mentioned study, it was determined that female employees were exposed to violence incidents $(63.3 \%)$ much more.

It was determined that the majority of the healthcare professionals who triggered the white code sequence in the case of WPV were women. It was the same when they witness a violence incident, if the white code was not triggered by the victim yet, female workers were ready to trigger it.

In the studies conducted by [22-23], it was stated that the average age of the employees who were exposed to WPV was below 39. While [24] determined that the healthcare professionals who were exposed to WPV, the most had undergraduate degrees. However, in our research it was revealed that this rate was higher among participants who had graduate school degrees.

It was seen in the study that; $63.3 \%$ of the participants experienced anxiety about facing violence while performing their duties. The fact that more than half of the participants are worried about encountering violence again but have not received any psychological counseling service is an important result needing more research to be applied. It was observed that there was a significant, positive, and lowlevel relationship $(\mathrm{p}=0.032)$ between the genders of healthcare personnel and their anxiety about facing violence while performing their duties.

It was seen that there was a significant, positive and mid-level relationship between the genders of the participants and their white code application training status ( $\mathrm{p}$ $=0.001)$ and those who received white code training (70.3\%) were mostly female participants. Furthermore, it was seen that at the time of the WPV incident, $66.7 \%$ of the participants working alone were female. Emergency services were the places where the most violence was expe- rienced $(35.8 \%)$. Hallways and examination rooms are also places where violence against healthcare workers frequently occurs. It may be beneficial if the healthcare managers to pay special attention to these locations within the hospitals to reduce violence.

No significant relationship was found between the genders of the healthcare workers and their opinion whether the white code was effective in preventing violence or not $(p=0.102)$. Along with this, most of the participants believe that white code application had a positive impact on preventing WPV incidents. It can be concluded that the white code application had created a safety feeling on participants. It is also remarkable that $60.5 \%$ of these participants were female. Still, further studies are needed to prove whether the implementation of white code application has any effect on the reason for participants not needing any treatment despite their psychological problems and anxieties.

Considering that the vast majority of the participants had not received any training on the white code application, it is a lack of healthcare managers to manage trainings about workplace violence issues including the use and aim of white code applications.

According to results, in the $76,1 \%$ of the incidents the white code team arrived at the incident point within first 1 -5 minutes after white code initiation and $90 \%$ of the incidents they arrived at the incident point within 10 minutes. According to the white code system manuals in the hospital, the goal of the white code team was to arrive at the target within 5 minutes and more than 10 minutes was declared as unacceptable. Results show that they have reached their goal at most but still more effort is required.

On the other hand, the fact that $69,7 \%$ of the participants stated that the incident was not inevitable, still, the 
participants continued to work while accepting that it was impossible to prevent the violence incidents they had experienced, therefore it might have caused them to think that they have to deal with these problems. Although most of the respondents think that white code was successful in terms of preventing violence, in more than half of the incidents they have stated that it was impossible to prevent the violence incidents which is a conclusion of the study that needs a detailed examination.

In the study $82.6 \%$ of the participants stated that judicial proceedings were carried out after the attack. On the other hand, $56 \%$ of the participants filed official complaints to press charges after the attack. This situation gives hints about the severity of the attack on healthcare workers and the degree how seriously they were affected.

According to our results, majority of the participants (79\%) had night shifts in addition to their daytime shifts. Also, it was determined that; $66.1 \%$ of the participants work between 40 and 50 hours a week, 33\% of them work between 50 and 70 hours a week. Our results were consistent with other studies [25]. According to these results, it could be stated that the increase of working hours may strengthen the possibility of exposure to WPV [26].

The participants stated that the application of white code is effective by leading the operation of the judicial process, but it is not considered as a deterrent element although it contributes to preventing violence. Participants believe that patients and their relatives lack the awareness and they feel entitled to use violence are root causes of WPV. It is clear that white code application cannot be alone considered as sufficient in preventing violence. It should be supported in some ways. For example; the legal processes are too long and the punishments are not adequately deterrent, in meanwhile it is also necessary to raise awareness of patients and their relatives about white code applications and violence and its possible consequences.

Finally, we suggest in order to prevent or decrease the number of WPV incidents; white code applications should be implemented in healthcare institutions, healthcare professional should be trained about WPV, how to keep from violence incidents and what to do in case of WPV, make them feel that the managers and the institution are behind them. It is also essential to inform patients and patient relatives on white code applications and raise their awareness of possible legal results of violence, make arrangements on speeding up the legal procedures, take legislative actions and follow regulations in order to increase the deterrence of the punishments. In addition, experienced (in terms of age and seniority) workers may be employed especially in risky places and limited shifts in shorter timespan should be organized all over the hospitals to decrease tiredness, stress and intolerance to avoid the possibility of WPV.

Our experiences in the field have lead us to believe that the actual rate of WPV is probably much higher than it is given in the literature due to underreporting. It is estimated that $70 \%$ of WPV are never reported, often nothing is done to help the employees who face WPV and hospital managers may even discourage them from reporting it. This is a very high rate which requires urgent attention of ministry of health in many countries.

\section{RECOMMENDATION}

We suggest researchers to examine the real number of WPV incidents in healthcare instutitions using new methods and compare the numbers of reported and unreported incidents which will better demonstrate the seriousness of violence towards healthcare professionals. 
Author Contributions: Research idea creation, design by YYİ and GA; data collection by GA, the analysis, comment and reporting of the article were done by YYI and GA.

Conflict of InTERest: The authors declare that there is no conflict of interest, and that the research and publication ethics are complied with in the article.

Financial Disclosure: The authors declare that this study did not receive any financial support from any person, institution or organization.

Ethics Committee Approval: In order to conduct the research, necessary permissions were obtained from Afyonkarahisar Public Hospital and Afyonkarahisar Provincial Health Directorate and ethics permission was obtained from Afyonkarahisar Health Sciences University Clinical Research Ethics Committee (No: 44946004602.01.01/2018). Researchers declare that the article follows research and publication ethics.

\section{REFERENCES}

[1] Çelik, Y. (2019) Health Economics, Political Bookstore, Ankara.

[2] Can, S.,and Haylı, Ç.M. (2020). Violence against health workers and measures to prev violence. International Journal of Health Services Research and Policy, 5.2,189-193.

[3] İleri, YY. (2018). Sağlık Yönetim Bilişim Sistemleri, Çizgi Kitabevi, Konya.

[4] McMahon, M. (2007). The Many Codes for a Disaster: A Plea for Standardization, Disaster Management \& Response, Vol. 5, No. 1, pp. 1-2, 20.

[5] Centers for Disease Control and Prevention (CDC), (2002). Violence: Occupational Hazards in Hospital: National Institutefor Occupational Safety and Health (NIOSH), Cincinnati, OH, USA.

[6] Word Health Organization, https://www.who.int.

[7] Kamchuchat,C.,Chongsuvivatwong, V., Oncheunjit, S., Yip, T.W., Sangthong, R., (2008). Workplace violence directedat nursing staff at a general hospital in southern Thailand.J." Occup. Health, 50, 201207.

[8] Kitaneh, M., Hamdan, M., (2012)Workplace violence against physicians and nurses in Palestinian public hospitals: A cross-sectional study, BMC Health Serv. Res.12, 469.

[9] Hesketh, T., Wu, D., Mao, L., Ma, N.(2012). Violence against doctors in China”, BMJ, 345-358.

[10] Parlar, S., (2008). Sağlık Çalışanlarında Göz Ardı Edilen Bir Durum: Sağlıklı Çalışma Ortamı, TAF Preventive Medicine Bulletin, 7(6), 547-554.

[11] Magnavita, N., (2014). Workplace violence and occupational stress in healthcare workers: A chickenand-egg situation. Results of a 6-year follow-up study, J. Nurs. Scholarsh, 46, 366-376.

[12] Annagür, B. (2010). Violence Against Healthcare Professionals: Risk Factors, Effects, Evaluation and Prevention, Current Approaches in Psychiatry, 2 (2), 161-173.

[13] Turkan, S. (2013). Analysis on Violence against Healthcare Professionals, Andrology Bulletin, 55, 254-260.

[14] Akça, N., Yılmaz, A., Işık, O. (2014). Violence Against Healthcare Professionals: A Special Medicine Center Sample, Ankara Health Services Journal, 13 (1), 1-11.

[15] Bıçkıcı, F. (2013).Violence Against Healthcare Professionals and Causing Factors: A State Hospital Case, Journal of Performance and Quality in Health, 5, 43-56.

[16] Wang, J., Zhao, L. (2013). Present situation and countermeasure research progress of hospital Violence, J. Med. Soc., 3, 13-15.

[17] Karasar, N. (2013). Scientific research methods, Ankara, Nobel Publishing House.

[18] Elliott, PP. (1997) Violence in health care. What nurse managers need to know: Nurs Manage, 28,384.

[19] Ferri, P., Silvestri M, Artoni C, Di Lorenzo R. (2016). Workplace violence in different settings and among various health professionals in an Italian general hospital: a cross-sectional study". Psychol Res Behav Manag., 9:263-275.

[20] Kowalenko, T., Gates D., Gillespie GL., Succop P., Mentzel TK.(2013). Prospective study of violence against ED workers" Am J Emerg Med., 31(1), 197205.

[21] Kaya, O. (2017) Investigation of White Code Cases Given at Bağcılar Training and Research Hospital between February-August 2014-2015 and its Effect on Health Personnel Subjected to Violence, Ministry of Health Health Sciences University Bağcllar Train- 
ing and Research Hospital, Emergency Medicine Clinic, Emergency Medicine Specialization Thesis, Istanbul.

[22] Günay.,Y.,Akbay, M.Ö.(2001). Workplace Violence, Working Environment Magazine,

[23] Arnetz, J., Arnetz, B., Petterson, I.(1996).Violence in the nursing profession: Occupational and lifesytle risk factors in Swedish nurses, Work Stress, Taylor \& Francis (Routledge) 10, 119-127.

[24] Çamc1, O., Kutlu Y.(2011) Workplace Violence Against Healthcare Professionals in Kocaeli Determination, Journal of Psychiatric Nursing, 2(1), 9-16.

[25] Tekin, H.H., Sevinç, İ. (2017) Assessment of Mobbing Exposure of Nurses And Their Stresses In The Context of Social Work Profession, The Journal of Academic Social Science, 5 (56), 522-534.

[26] Ileri, Y. Y., Arik, O. (2018). Investigation of Resistance, Perception and Attitudes of Employees against Change in Information Systems Using Change Management Approach: A Study in a University Hospital. Journal of Information \& Knowledge Management, 17(04), 1850038. 